\title{
Growers' knowledge on spices cultivation in Shibganj upazila under Bogura district
}

\author{
M.S.I. Afrad ${ }^{1 *}$ and M.R. Akter ${ }^{2}$ \\ Received 21 April 2020, Revised 3 June 2020, Accepted 20 June 2020, Published online 30 June 2020
}

\section{A B S T R A C T}

The main objective guided the present study was to evaluate the knowledge of the growers on spices cultivation practice in Shibganj upazila under Bogura district. Three unions of the upazila were purposively selected based on the vicinity to the Spices Research Center, Bogura. Data were collected from selected growers using predesigned structured interview schedule. Eleven selected characteristics of the growers were considered as independent variables. As dependent variable, knowledge on spices cultivation practice was calculated by construction of a scale containing thirteen relevant questions. Coefficient of correlation was employed to determine the relationship between the selected characteristics of the growers and their knowledge on spices cultivation practice. Majority $(67.8 \%)$ of the growers were middle aged, the highest portion (61.1\%) of them belonged to primary level education. Major proportion (60.0\%) of them had small family size, almost all of them (98.9\%) possessed small to medium farm size, and huge majority $(87.8 \%)$ of them earned up to BDT 240000 annually. About three-fourth (73.3\%) of the farmers had medium extension contact, half of them (50.0\%) had poor training experience while 40.0 percent of them had medium innovativeness. Great majority (85.5\%) of the farmers had small to medium spices cultivation area (up to 0.6 ha) while almost three-fourth (72.2\%) of them had medium to long durational (11 to above 20 years) practice of spices cultivation. Majority (65.6\%) of them had moderate knowledge on spices cultivation technology compared to more than onefourth (26.7\%) having high knowledge and only 7.7 percent had low knowledge on the same. None of the selected characteristics showed significant relationship with the knowledge on spices cultivation practice.

Keywords: Spices, Practice, Knowledge, Cultivation, Bogura district.

${ }^{1}$ Professor, Department of Agricultural Extension and Rural Development, BSMRAU, Gazipur, Bangladesh.

${ }^{2}$ Former MS Student, Department of Agricultural Extension and Rural Development, BSMRAU, Gazipur, Bangladesh.

*Corresponding author's email: afrad69@gmail.com (M.S.I. Afrad)

Cite this article as: Afrad, M.S.I. and Akter, M.R. 2020. Growers' knowledge on spices cultivation practice in Shibganj upazila under Bogura district. Int. J. Agril. Res. Innov. Tech. 10(1): 102-107. https://doi.org/10.3329/ijarit.v10i1.48101

\section{Introduction}

Herbal by-products that add flavor and aesthetic, aromatic and therapeutic treatments to food, drink and other items are generally termed as spices (Kumar et al., 2011). Spices may be either bark, buds, flowers, fruits, leaves, rhizomes, roots, seeds, stigmas and styles or the entire plant tops (Takeda et al., 2008). Spices and condiments play quite an important role in the national economies of several spice-producing, importing and exporting countries of the world. Spice production is a part of horticultural industry, which has a significant contribution to livelihood of smallholder farmers in Asia, Latin America and Africa (IFAD, 2009) whereby about 86 types of spices are grown (Panda, 2010). Presently 109 kinds of spices are cultivated in the world but in Bangladesh, only 27 are used and produced only 17. Based on area, yield, demand and availability, spices are divided into three categories viz. major, minor and exotic. Major spices are regularly used in daily diet at large amount such as chili, onion, garlic, turmeric and ginger (Islam et al., 2011). Spices provide means of earning living to many who operate on any of the activities within its value chain and are more profitable compared with other competing crops (CAST, 1984; Elias and Hossain, 1984).

In Bangladesh, the area under the spices cultivation is 0.4 million hectares with annual production of 2.5 million metric tons and the annual demand of spices seeds are 3.0 million metric tons. Spices cover almost 2.6 percent of total cropped area in Bangladesh (BBS, 2016). 
Recently, the production rate of major spices like onion, garlic, chili, turmeric and ginger are 0.174 , $3.82,0.130,0.140$ and 0.077 million metric tons, respectively (BBS, 2016). The average area and production of spices are increasing in Bangladesh. However, it is reported that shrinkage of land resources is a limited scope to increase production of spices (Noor et al., 2008). Several research organizations are involved in research to improve the production and quality of spices. For the last two decades, BARI developed and released 18 (major-12, minor-6) disease resistance improved variety of spices. On the other hand, 81 technology on production, soil and water management; disease and insect management and post-harvest management have also been developed. BARI, BARC, DAE and NGO's have strengthened their works to extend these technologies (Islam et al., 2011). However, the Bangladesh national demand of spice consumption is much higher than production. Considering the importance of spices in Bangladesh, Spices Research Centre (SRC) was established under Bangladesh Agriculture Research Institute (BARI) in Shibganj upazila under Bogura district in 1996. So far, 33 highyielding varieties of 14 crop spices were invented along with 150-production technology, which detailed how the high-yielding varieties should be planted and grown to ensure high standard.

For successful production of spices, it is very important to acquire knowledge of spices cultivation practice by the growers. Because, there is significant relationship between agricultural knowledge and adoption of agricultural technology (Reddy et al., 1987; Akter, 2007). However, there is dearth of research on knowledge of the growers on spices cultivation practice. If the level of production knowledge held by the growers is identified, it would be easier for effective cultivation of spices. Therefore, the present study was undertaken to: i) describe the socio-economic characteristics of the spices growers in the study area, ii) determine the knowledge of spices cultivation practice by the growers in the selected study area and iii) find out the relationships between socio-economic characteristics of the respondents and their knowledge on spices cultivation practice.

\section{Methodology}

The descriptive and diagnostic research design was used in the present study. The study was conducted in three unions (Shibganj Sadar, Mokamtala, and Bihar) of Shibganj upazila under Bogura district. Shibganj upazila of Bogura district was selected as because spices cultivation is widely distributed in this area. All the spices cultivators of Shibganj upazila under Bogura district constituted the population of this study. Total number of the spices cultivators in the three unions was 270 that constituted sampled population of the study. In this study, 90 farmers were selected as sample following random sampling technique. In order to collect relevant information from the respondents, a structured interview schedule was carefully designed keeping the objectives of the study in view. The schedule contained both open and closed form questions. The researchers collected data during October to December 2018. The independent variables of the study were age, education, family size, farming experience, farm size, training experience, innovativeness, annual family income, extension contact, area under spices cultivation and duration of spices cultivation whereas knowledge on spices cultivation practice was the dependent variable.

Age, education of the respondents was measured in actual year and categorized following Rahman (2008) and training experience following Wadud (2010). Family size was measured in numbers of total member and farm size in hectare following Islam (2008) and BBS (2009). Annual family income was calculated in BDT (Bangladeshi Taka), innovativeness in observed score, farming experience in years, extension contact in observed score. Area under spices cultivation was measured in hectare and duration of spices cultivation was measured in years. Knowledge on modern spices cultivation practice was measured by preparing a scale consisting of 13 related questions assigning ' 2 ' marks for each. A respondent was assigned "full marks" for correct answering, "half marks" for partial answering and "no marks" for wrong answering of any question. Total marks of the all respondents obtained from answering the entire thirteen questions. The variables were categorized based on observed mean and SD.

\section{Results and Discussions}

This section has been described into the following sub-sections as per objectives of the study.

\section{Descriptive characteristics of the respondents}

Eleven socioeconomic characteristics of the respondents were considered in this study as the independent variables. However, nine of these have been presented in Table 1. Results indicate that big majority (86.7\%) of the respondents were young to middle aged categories and almost all (96.7\%) of them with literacy of primary to higher secondary level. Greater part of the respondents (98.9\%) possessed small to medium sized farm and the equal portion of them belonged to small to medium family categories. Very great majority of the respondents earned BDT 110000 to 240000 annually. More than three-fourth (77.8\%) of the respondents showed moderate to very high categories innovativeness. 
Table 1. Distribution of the respondents according to their selected characteristics.

\begin{tabular}{|c|c|c|c|c|c|c|c|}
\hline \multirow{2}{*}{$\begin{array}{l}\text { Variables (Unit of } \\
\text { measurement) }\end{array}$} & \multicolumn{2}{|c|}{ Score range } & \multirow[t]{2}{*}{ Categories } & \multirow[t]{2}{*}{ No. } & \multirow[t]{2}{*}{$\%$} & \multirow[t]{2}{*}{ Mean } & \multirow[t]{2}{*}{ SD } \\
\hline & Possible & Observed & & & & & \\
\hline \multirow{3}{*}{ Age (Years) } & \multirow{3}{*}{ Unknown } & 28 & Young (22 to 35 ) & 17 & 18.9 & \multirow{3}{*}{42.09} & \multirow{3}{*}{ - } \\
\hline & & to & Middle ( 36 to 50 ) & 61 & 67.8 & & \\
\hline & & 56 & Old (51 and above) & 12 & 13.3 & & \\
\hline \multirow{4}{*}{$\begin{array}{l}\text { Education } \\
\text { (Schooling years) }\end{array}$} & \multirow{4}{*}{ Unknown } & \multirow{4}{*}{$0-12$} & Illiterate (o) & 3 & 3.3 & \multirow{4}{*}{$5 \cdot 32$} & \multirow{4}{*}{3.06} \\
\hline & & & Primary ( 1 to 5 ) & 55 & 61.1 & & \\
\hline & & & Secondary (6 to 10$)$ & 29 & 32.3 & & \\
\hline & & & Higher secondary (above 10) & 3 & 3.3 & & \\
\hline \multirow{3}{*}{$\begin{array}{l}\text { Family size } \\
\text { (Number) }\end{array}$} & \multirow{3}{*}{ Unknown } & \multirow{3}{*}{$2-8$} & Small $(<5)$ & 54 & 60.0 & \multirow{3}{*}{4.32} & \multirow{3}{*}{1.29} \\
\hline & & & Medium (5-7) & 35 & 38.9 & & \\
\hline & & & Large (above 7) & 1 & 1.1 & & \\
\hline \multirow{3}{*}{ Farm size (ha) } & \multirow{3}{*}{ Unknown } & \multirow{3}{*}{$\begin{array}{c}0.530 \\
\text { to } \\
4.008\end{array}$} & Small (0.02 to 1.01$)$ & 43 & 47.8 & \multirow{3}{*}{1.03} & \multirow{3}{*}{0.43} \\
\hline & & & Medium (above 1.01to 3.03) & 46 & 51.1 & & \\
\hline & & & Large (above 3.03) & 1 & 1.1 & & \\
\hline \multirow{3}{*}{$\begin{array}{l}\text { Annual income } \\
\left({ }^{*} \text { Tk.) }\right.\end{array}$} & \multirow{3}{*}{ Unknown } & \multirow{3}{*}{$\begin{array}{c}80000 \\
\text { to } \\
350000\end{array}$} & Low ( up to 1100oo) & 43 & 47.8 & & \\
\hline & & & Medium (110001 to 240000 ) & 36 & 40.0 & 148978 & - \\
\hline & & & High ( above 24000o) & 11 & 12.2 & & \\
\hline & & & Low (1) & 20 & 22.2 & & \\
\hline Innovativeness & & & Medium (2) & 36 & 40.0 & & \\
\hline (Score) & $1-4$ & $1-4$ & $\operatorname{High}(3)$ & 22 & 24.5 & 2.29 & - \\
\hline & & & Very high (4) & 12 & 13.3 & & \\
\hline & & & Low (1 to 10$)$ & 6 & 6.7 & & \\
\hline Farming & Unknown & $10-32$ & Medium (11 to 20 ) & 36 & 40.0 & 21.10 & 7.24 \\
\hline & & & High ( above 20) & 48 & 53.3 & & \\
\hline & & & No (o) & 7 & 7.7 & & \\
\hline & & & Poor (1-3) & 33 & 36.7 & & \\
\hline experience (Days) & Unknown & $0-8$ & Medium (4-5) & 33 & 36.7 & 3.58 & - \\
\hline & & & High (above 5) & 17 & 18.9 & & \\
\hline & & & Low (1 to 5$)$ & 11 & 12.2 & & \\
\hline Extension contact & $0-12$ & $5-11$ & Medium (6 to 10$)$ & 66 & 73.3 & 8.42 & 1.61 \\
\hline & & & High ( above 10 ) & 13 & 14.5 & & \\
\hline
\end{tabular}

${ }^{*} 1 \mathrm{USD}=85 \mathrm{Tk}$.

Almost all (93.3\%) of the respondents showed one to above twenty years farming experience. Approximately three-fourth (73.4\%) of the respondents received one to five training regarding different agricultural and rural development issues. Vital majority (87.8\%) of the respondents had six to above ten extension contact with the various extension personnel.

\section{Area under spices cultivation}

The mean and standard deviation of spices cultivation area were 0.41 ha and 0.13 , respectively. Information presented in Table 2 indicate that the majority $(43.3 \%)$ of the respondents had small cultivation area while the more or less same portion (42.2\%) had medium and only 14.5 percent of them had large spices cultivation area. Therefore, more than four-fifth (85.5\%) of the respondent belonged to small to medium spices cultivation area.

Table 2. Distribution of the respondents based on their spices cultivation area

\begin{tabular}{|c|c|c|c|c|}
\hline \multirow[t]{2}{*}{ Categories } & \multicolumn{2}{|c|}{ Respondents } & \multirow[t]{2}{*}{ Mean } & \multirow[t]{2}{*}{$\mathrm{SD}$} \\
\hline & Number & Percent & & \\
\hline Small spices cultivation area (0.10 to $0.30 \mathrm{ha}$ ) & 39 & 43.3 & \multirow[t]{4}{*}{0.41} & \multirow[t]{4}{*}{0.13} \\
\hline Medium spices cultivation area (0.31 to $0.60 \mathrm{ha})$ & 38 & 42.2 & & \\
\hline Large spices cultivation area ( above $0.60 \mathrm{ha}$ ) & 13 & 14.5 & & \\
\hline Total & 90 & 100.0 & & \\
\hline
\end{tabular}

The findings clearly indicate that most of the respondent farmers had small to medium spices cultivation area (up to $0.6 \mathrm{ha}$ ). This might be due to their possession of total small land holdings. 


\section{Duration of practicing spices cultivation}

Based on the age of practicing spices, respondents were classified into three categories
(Table 3). The mean and standard deviation of spices practicing were 17.58 years and 6.76 , respectively.

Table 3. Distribution of the respondents based on their duration of practicing spices cultivation.

\begin{tabular}{|c|c|c|c|c|}
\hline \multirow[t]{2}{*}{ Categories } & \multicolumn{2}{|c|}{ Respondents } & \multirow[t]{2}{*}{ Mean } & \multirow[t]{2}{*}{ SD } \\
\hline & Number & Percent & & \\
\hline Short durational practice (1 to 10 years) & 25 & 27.8 & 17.58 & 6.76 \\
\hline Medium durational practice (11 to 20 years) & 36 & 40.0 & & \\
\hline Long durational practice (above 20 years) & 29 & 32.2 & & \\
\hline Total & 90 & 100.0 & & \\
\hline
\end{tabular}

Results presented in Table 3 indicate that the majority (40.0\%) of the respondents had medium durational practice of spices cultivation while 32.2 percent had long and 27.8 percent had short durational practice of spices cultivation. Therefore, it is clearly indicated that almost three-fourth $(72.2 \%)$ of the respondent farmers had medium to long durational (11 to above 20 years) practice of spices cultivation. This might be due to high income from spices cultivation,

Knowledge on modern spices cultivation practice

Observed knowledge scores of the farmers ranged from ' 8 ' to '24' against possible range of ' 0 ' to ' 26 ' with mean and standard deviation were 18.13 and 3.55 respectively. For clear understanding about knowledge level of the spices growers, detailed explanations of different knowledge items are illustrated in Table 4. tradition of area and familiar cultivation technique.

Table 4. Distribution of the respondents based on their knowledge on spices cultivation practice

\begin{tabular}{|c|c|c|c|c|c|}
\hline \multirow[t]{3}{*}{ Sl.\# } & \multirow[t]{3}{*}{ Questions on spices cultivation practice } & \multicolumn{4}{|c|}{ Response type $(\mathrm{n}=90)$} \\
\hline & & \multicolumn{2}{|c|}{ Correct } & \multicolumn{2}{|c|}{$\begin{array}{l}\text { Partially } \\
\text { correct }\end{array}$} \\
\hline & & $\mathrm{N}$ & $\%$ & $\mathrm{~N}$ & $\%$ \\
\hline 01 & $\begin{array}{l}\text { Why temperature is an important factor for spices } \\
\text { production? }\end{array}$ & 82 & 91.1 & 8 & 8.9 \\
\hline 02 & What kind of soil is suitable for onion cultivation? & 21 & 70.0 & 9 & 30.0 \\
\hline 03 & What is the optimum planting time of onion? & 15 & 50.0 & 15 & 50.0 \\
\hline 04 & $\begin{array}{l}\text { Mention the name of one disease and one insect that cause } \\
\text { damage to onion. }\end{array}$ & 6 & 20.0 & 24 & 80.0 \\
\hline 05 & $\begin{array}{l}\text { Why does closer spacing give higher yield than wider spacing } \\
\text { in turmeric? }\end{array}$ & 18 & 60.0 & 12 & 40.0 \\
\hline 06 & Mention the ideal planting time of turmeric & 20 & 66.7 & 10 & $33 \cdot 3$ \\
\hline 07 & $\begin{array}{l}\text { What are the impact of time of planting over the seed yield of } \\
\text { spices and incidence of the disease? }\end{array}$ & 90 & 100.0 & 0 & 0.0 \\
\hline 08 & What is the optimum spacing for ginger cultivation? & 12 & 40.0 & 18 & 60.0 \\
\hline 09 & Which day temperature is ideal for ginger? & 15 & 50.0 & 15 & 50.0 \\
\hline 10 & Mention the name of two HYV varieties of onion. & 18 & 60.0 & 12 & 40.0 \\
\hline 11 & $\begin{array}{l}\text { For medium fertile land, which fertilizers will you apply to } \\
\text { obtain good yield of spices? }\end{array}$ & 50 & 55.6 & 40 & 44.4 \\
\hline 12 & Mention two varieties of turmeric developed by BARI & 12 & 40.0 & 18 & 60.0 \\
\hline 13 & $\begin{array}{l}\text { How do manuring and fertilization are essential factors for } \\
\text { producing higher yield of spices? }\end{array}$ & 90 & 100.0 & o & 0.0 \\
\hline
\end{tabular}

Results shown in Table 4 reveal that 100.0 percent of the respondents answered correctly the planting time has great impact over the seed yield of spices and incidence of the diseases and manuring and fertilization are essential factors for producing higher yield of spices. On the other hand, 91.1 percent correctly and 8.9 percent partial correctly knew that temperature is an important factor for spices production. Whereas most of the respondent farmers had very poor knowledge about optimum spacing (60.0\%), suitable soil (55.6\%), ideal planting time (66.7\%) etc. of spices. Based on the knowledge scores, the farmers were classified into three categories as shown in Table 5 . 
Table 5. Distribution of the respondents according to their knowledge on spices cultivation practice.

\begin{tabular}{|c|c|c|c|c|c|c|c|}
\hline \multirow{2}{*}{$\begin{array}{c}\text { Variables (Unit of } \\
\text { measurement) }\end{array}$} & \multicolumn{2}{|c|}{ Score range } & \multirow[t]{2}{*}{ Categories } & \multicolumn{2}{|c|}{ Respondents } & \multirow[t]{2}{*}{ Mean } & \multirow[t]{2}{*}{ SD } \\
\hline & Possible & Observed & & No. & $\%$ & & \\
\hline \multirow{2}{*}{$\begin{array}{l}\text { Knowledge on } \\
\text { spices cultivation } \\
\text { practice (Score) }\end{array}$} & \multirow[b]{2}{*}{$0-26$} & \multirow[b]{2}{*}{$8-24$} & Low (up to 10) & 7 & 7. & \multirow[b]{2}{*}{18.13} & \multirow[b]{2}{*}{$3 \cdot 55$} \\
\hline & & & $\begin{array}{l}\text { Moderate (11-20) } \\
\text { High (above 20) }\end{array}$ & $\begin{array}{l}59 \\
24\end{array}$ & $\frac{65.6}{267}$ & & \\
\hline
\end{tabular}

Results contained in Table 5 indicate that the majority (65.6\%) of the respondent farmers had moderate knowledge on spices cultivation practice compared to 26.7 percent having high knowledge and 7.7 percent had low knowledge. Thus, very big majority (92.3\%) of the respondent farmers in the study area had moderate to high category knowledge about spices cultivation practice. This might be due to their frequent contact with the sources of information, functional training on spices cultivation and durable farming experience. Chethan (2011) reported that 44.0 percent farmers possessed moderate knowledge on cardamom cultivation practices. Garu (2015) in his study also reported that majority of the

Table 6. Relationship between of the selected characteristics of the respondents and their knowledge on spices cultivation practice farmers (46.7\%) had low knowledge about organic spices, while only $33.3 \%$ had moderate knowledge on of organic spices and $20 \%$ of the farmers had the lowest knowledge.

\section{Relationship between the selected characteristics of the respondents and their knowledge on spices cultivation practices}

Correlation coefficient ' $r$ ' was calculated to find out the relationship between knowledge on spices technology and selected socioeconomic characteristics of the respondents. The summary of the correlation analysis has been shown in Table 6.

\begin{tabular}{|c|c|c|}
\hline Independent variable & Dependent variable & Coefficient of correlation (r) \\
\hline Age & \multirow{11}{*}{$\begin{array}{l}\text { Knowledge on spices } \\
\text { cultivation practice }\end{array}$} & $-0.015^{\mathrm{NS}}$ \\
\hline Education & & $-0.146^{\mathrm{NS}}$ \\
\hline Family size & & $-0.105^{\mathrm{NS}}$ \\
\hline Farm size & & $0.016^{\mathrm{NS}}$ \\
\hline Extension contact & & $-0.139^{N S}$ \\
\hline Farming experience & & $0.088^{\mathrm{NS}}$ \\
\hline Training experience & & $-0.045^{\mathrm{NS}}$ \\
\hline Innovativeness & & $0.038^{\mathrm{NS}}$ \\
\hline Annual family income & & $-0.125^{\mathrm{NS}}$ \\
\hline Area under spices cultivation & & $-0.073^{\mathrm{NS}}$ \\
\hline Duration in spices cultivation & & $0.102^{\mathrm{NS}}$ \\
\hline
\end{tabular}

$N S=$ Non-significant

Results shown in Table 6 indicate that all of the nine selected variables of the respondents showed non-significant relationship with their knowledge on spices cultivation practice. Farm size, farming experience, innovativeness and duration in spices cultivation were positively correlated knowledge on spices cultivation practice. It means that higher the farm size, farming experience, innovativeness and duration in spices cultivation, higher the knowledge on spices cultivation practice. Vasanthakumar (2000), Gandhi (2002), Shashidhar (2006) in their studies also reported non-significant relationships of innovativeness, farm size and farming experience with the knowledge of the coffee, tomato, vegetable growers, respectively. On the other hand, age, education, family size, extension contact, training experience and annual income, farming experience, farm size and area under spices cultivation were negatively correlated. It indicates that higher the age, education, family size, extension contact, training experience, annual family income and area under spices cultivation, lower the knowledge on spices cultivation practice. Umeh et al. (2018) and Kadam (1999) found negative significant relationships between age and knowledge of the pomegranate and role of extension service, respectively.

\section{Conclusions}

Great majority of the growers were between young to middle aged, having primary level education, small family size, medium farm size, low annual income, medium extension contact, poor training experience and medium innovativeness. Big majority of the farmers had small to medium spices cultivation area and almost three-fourth of them had medium to long durational practice of spices cultivation. Poor knowledge of the respondent farmers was observed in optimum spacing, suitable soil and ideal planting time. of spices. Great majority of them had moderate to high-level knowledge on spices cultivation practice. None of the selected characteristics of the growers showed significant relationships with the knowledge on spices cultivation practice. However, age, education, family size, extension contact, training 
experience, annual family income and area under spices cultivation, indicated negative nonsignificant relationships with the knowledge of the growers on spices cultivation practice. Department of Agricultural extension may arrange suitable training program towards minimizing the knowledge gap of the farmers.

\section{References}

Akter, L. 2007. Adoption of Improved Tomato Varieties by the Farmers in a Selected Area of Bangladesh. MS (Agricultural Extension Education) Thesis, Bangladesh Agricultural University, Mymensingh.

BBS, 2009. Yearbook of Agricultural Statistics in Bangladesh, Bangladesh Bureau of Statistics, Ministry of Planning, Government of the People's Republic of Bangladesh, Dhaka.

BBS, 2016. Yearbook of Agricultural Statistics in Bangladesh, Bangladesh Bureau of Statistics, Ministry of Planning, Government of the people's Republic of Bangladesh, Dhaka.

CAST (Canadian Agricultural Sector Team). 1984. Production and Marketing of Spices in Bangladesh: A Background Report, Dhaka.

Chethan, M.G. 2011. A Study on Knowledge and Adoption of Cardamom Cultivation Practices by the Farmers of Chikmagalur District. MS Thesis, Department of Agricultural Extension Education, University of Agricultural Sciences, Dharwad, India.

Elias, S.M. and Hossain, M.I. 1984. Chili Cultivation in Bangladesh. Agro-Economic Survey and Constraints to Its Production at Farm Level, Gazipur, Bangladesh. Bangladesh Agricultural Research Institute (BARI), Gazipur, Bangladesh.

Gandhi, V.R. 2002. Knowledge Level and Adoption Behaviour of Vegetable Growers With Respect to Integrated Pest Management of Tomato Crop in Kolar District. M. Sc. (Agri.) Thesis, Univ. Agric. Sci., Dharwad, Karnataka (India).

Garu, F.A. 2015. Organic Spices Farming in West Districts, Zanzibar: its contribution to livelihood outcomes of smallholder farmers. MS (Arts in Rural Development) Thesis, Sokoine University of Agriculture. Morogoro, Tanzania.

IFAD. 2009. The Role of High Value Crops in Rural Poverty Reduction the Near and North Africa, Division. IFAD. 26p.

Islam, A. 2008. Farmers' Knowledge System and Dissemination of Mungbean Cultivation in the South-Western Region of Bangladesh. MS (Agricultural Extension and Rural Development) Thesis, Bangabandhu Sheikh Mujibur Rahman Agricultural University, Bangladesh.

Islam, M.S., Rahman, K.M. and Hasan, M.K. 2011. Profitability and Resource Use Efficiency of
Producing Major Spices in Bangladesh. Bangladesh J. Agril. Econ. 34: 1-2.

Kadam, R.P. 1999. A Study on Knowledge, Cultivation Practices Followed and Marketing Behavior of Sweet Orange Growers in Nanded District, Maharashtra State, M. Sc. (Agri.) Thesis, Univ. Agric. Sci., Dharwad, Karnataka (India).

Kumar, A., Kumar, A., Kaushal, V. Patil, S., Payal, C. and Kumar, A. 2011. Antibacterial Potential of Some Natural Food Preservatives against Staphylococcus aureus Isolated from various Food Samples of Himachal Pradesh (India), World J. Sci. Tech. 1(10): 48-53.

Noor, S., Khan, M.S., Shil, N.C. and Talukder, M.R. 2008. Integrated Nutrient Management for Sustainable Yield of Major Spice Crops in Bangladesh. Bangladesh $J$. Agril. Environ. 4: 95-113.

Panda, H. 2010. Handbook on Spices and Condiments (Cultivation, Processing and Extraction). Asia Pacific Business Press Inc., Delhi India. 640p.

Rahman, M.S. 2008. Farmers' Response towards Cultivation of BRRI dhan33 to Mitigate Monga. MS (Agricultural Extension and Rural Development) Thesis, Bangabandhu Sheikh Mujibur Rahman Agricultural University, Gazipur.

Reddy, P.R., Reddy, M.M. and Reddy, D.R. 1987. Impact of National Demonstration on Knowledge level, Attitude and Adoption Behavior of Farmers in Ranaga Reddy District of Andhra Pradesh State. J. Res. APAU. 15(1): 35-38.

Shashidhar, K.K. 2006. A Study on Management of Eco-Friendly Practices by Vegetable Growers of North Karnataka. PhD Dissertation, Univ. Agric. Sci., Dharwad, Karnataka (India).

Takeda, J., Silva, S.D., Muthuraman, P., Rahman, S.M. and Kawet, L. 2008. Spices in Sri Lanka, India and Bangladesh with Special Reference to the Usages and Consumptions. Bull. Fac. Agr., Saga Univ. 93: 1-25.

Umeh, O.J., Igwe, K.C. and Anyim, A. 2018. Farmers Knowledge of the Role of Extension Services in Akwa-Ibom State Nigeria. $J$. Agril. Ext. 22(3): 87-96. https://doi.org/10.4314/jae.v22i3.9

Vasanthakumar, M.P. 2000. A Study on Knowledge Adoption and Economic Performance of Coffee Growers in Virajpet Taluk of Coorg District. M. Sc. (Agri.) Thesis, Univ. Agric. Sci., Bangalore, Karnataka (India).

Wadud. F. 2010. Impact of Commercial Flower Cultivation on the Livelihood of Its Growers in Bangladesh. PhD (Agricultural Extension and Rural Development) Dissertation, Bangabandhu Sheikh Mujibur Rahman Agricultural University, Bangladesh. 